\title{
A STUDY ON HEALTH STATUS OF CHILDREN UNDER FIVE YEARS OF AGE IN A RURAL VILLAGE OF EASTERN PART OF NEPAL
}

\section{Dewa Adhikari}

\begin{abstract}
Introduction: Every needy child should receive the best medical and surgical attention. In 1940, the White house Conference proposed adequate health services including medical and dental examination, immunization and early detection and treatment of diseases, vision and hearing tests, prevention and control of disease, health records and health services facilities.
\end{abstract}

Objectives: To assess the health status of under five children. To know the treatment preference of the parents towards their sick children. To initiate control measures early, by allocating the health resources more efficiently and providing health awareness activities.

Materials and Methods: Descriptive cross-sectional study was conducted. The entire 1-5 years age child (40children) residing in Dharan Municipality ward. No-17 at Phoklen Tapu was included. Simple random sampling technique (lottery method) was used to select the village and Census survey technique was followed to find out the 1-5 years children. The survey was conducted by investigator herself and self develop tools were used to health status of the child.

Results: Most of the morbid conditions founded in the study were related to skin diseases (ring worm, boils/wound, cuts, eczema/ redness), ear infection, enlarged lymph node, Pneumonia, Diarrhoea/ vomiting, abdominal enlargement and malnutrition with different Grade.

Conclusion: Majority of the parent were not having health education regarding child care. The treat their child with home remedies, by faith healer then after third time they seek sick child with health personnel.

Key words: Children, Children's' health status, Nepal

\section{Introduction}

According to the constitution of World Health organization $(1948)^{1}$, healthy development of the child is of basic importance, the ability to live harmoniously in a changing total environment is essential to such development" The convention on the rights of the child adapted by the general assembly of the United Nation in 1989 is a set of international standards and measures intended to protect and promote the well being of the children in society. ${ }^{2}$

Under the rights of the three vital components are recognized: health, food and care. It was decided in 1997 that the main goal of WHO and governments should be the health for all (HFA) by 2000. The essential principle of HFA is the concept of equity in the health I.E. all people should have an opportunity to enjoy good health. ${ }^{3}$ so for the 
good health, ongoing investments are needed. Only then, a child can grow and develop into a useful competent asset, participating as an adult member to the community as well as nation. Their healthy life depends upon their parents, community people and health care system.

At the white house conference (WHC) on the care of the Department of children, it was proposed that "every needy child should receive the best medical and surgical attention. In 1940, the WHC proposed adequate health services including thorough medical and dental examination, immunization and early detection and treatment of diseases, vision and hearing tests, prevention and control of disease, health records and health services facilities. ${ }^{8}$

Nepal is facing the vicious cycle of PPE spiral I.e. Poverty, population explosion, and environmental degradation. However various types of governmental and nongovernmental health programmes have been launched from time to time but they are still need improvement.the concrete efforts to care to the under 5 through agencies still remains to be provided regularly. The recent NDHS report showed that $13 \%$ ( 41.94 Million) are underfive of the total population (23.2million, 2001). This is one of the highest ratios of child population in the world.

Therefore considering the amount magnitude of problems this study was carried out with objectives to assess the health status of childrens' below five years of age residing in ward 17 of Dharan municipality. This study also aimed to find out the possible anthropometric measurements of subjects and also to detect the early warning signal of the disease and other possible common morbidities among subjects and to know the treatment preference of their parents.

\section{Materials and Methods}

A cross sectional descriptive study, which catered all entire population of children below age of 5 years of a selected ward of Dharan municipality was carried out within a period of one year beginning from 15 January 2011. A simple random sampling technique (lottery method) was used to select the study area and Census survey technique was followed to find out the children below age 5 years.

A specifically designed questionnaire was used to record all necessary information. Consent from the parent was obtained. The available information kept confidential and double entered in to a personal computer and analysed using SPSS 11.5 version.

\section{Results}

\section{Table1: Distribution of Children by Gender}

\begin{tabular}{|c|c|c|c|}
\hline \multirow{2}{*}{$\begin{array}{c}\text { Age in } \\
\text { Years }\end{array}$} & Boys & Girls & Total \\
\cline { 2 - 4 } & NO & No & NO/\% \\
\hline 1 Year & 1 & 1 & $2(5 \%)$ \\
\hline 2 Years & 1 & 1 & $2(5 \%)$ \\
\hline 3 Years & 7 & 5 & $12(30 \%)$ \\
\hline 4 Years & 6 & 10 & $16(48 \%$ \\
\hline 5 Years & 3 & 5 & $8(24 \%)$ \\
\hline Total & $\mathbf{1 8}$ & $\mathbf{2 2}$ & $\mathbf{4 0}(\mathbf{1 0 0} \%)$ \\
\hline
\end{tabular}

Table no 1: shows that both genders were distributed equally in among the sample population there were 22 girls and 18 boys. 
Fig. 1 shows that majority of the childrens were from Disadvantaged Janajati $70 \%$.

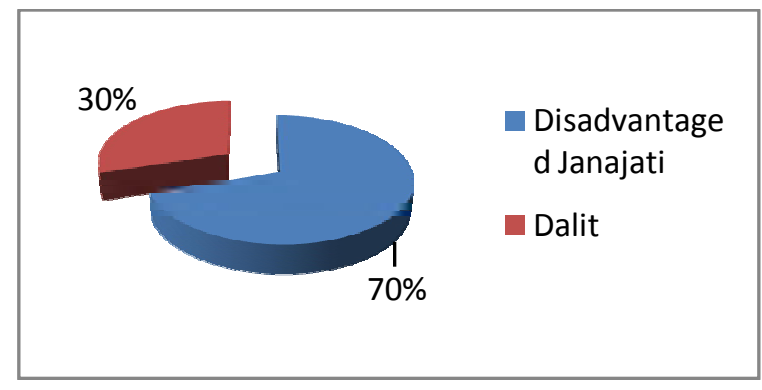

Fig. 1: Distribution of Cast/Ethnicity among under five children

Table 2: Personal Hygiene of the Children

\begin{tabular}{|c|c|c|}
\hline Hygiene & $\mathrm{No}_{0}=\mathbf{4 0}$ & $\%$ \\
\hline $\begin{array}{l}\text { Skin: clean } \\
\text { Dirty }\end{array}$ & $\begin{array}{c}6 \\
34\end{array}$ & $\begin{array}{l}15 \% \\
85 \%\end{array}$ \\
\hline $\begin{array}{l}\text { Cloths : clean } \\
\text { Dirty }\end{array}$ & $\begin{array}{l}10 \\
30\end{array}$ & $\begin{array}{l}25 \% \\
75 \%\end{array}$ \\
\hline $\begin{array}{c}\text { Bath: Once a week } \\
\text { Daily } \\
\text { When get dirty }\end{array}$ & $\begin{array}{c}34 \\
4 \\
2\end{array}$ & $\begin{array}{l}85 \% \\
10 \% \\
5 \%\end{array}$ \\
\hline $\begin{array}{l}\text { Hair: clean } \\
\text { Not clean } \\
\text { Pediculosis } \\
\text { Dandraff }\end{array}$ & $\begin{array}{c}2 \\
19 \\
9 \\
10\end{array}$ & $\begin{array}{c}5 \% \\
47.5 \% \\
22.5 \% \\
25 \%\end{array}$ \\
\hline $\begin{array}{l}\text { Nose: clean } \\
\text { Running } \\
\text { Blockage/ } \\
\text { obstruction }\end{array}$ & $\begin{array}{c}10 \\
25 \\
5\end{array}$ & $\begin{array}{c}25 \% \\
62.5 \% \\
12.5 \%\end{array}$ \\
\hline $\begin{array}{c}\text { Mouth: Healthy soft } \\
\text { Dirty } \\
\text { Angular } \\
\text { stomatitis }\end{array}$ & $\begin{array}{c}20 \\
14 \\
6\end{array}$ & $\begin{array}{l}50 \% \\
35 \% \\
15 \%\end{array}$ \\
\hline $\begin{array}{l}\text { Teeth: healthy/ soft } \\
\text { Dental carries } \\
\text { Swollen/ bleed }\end{array}$ & $\begin{array}{c}11 \\
24 \\
5\end{array}$ & $\begin{array}{c}27.5 \% \\
60 \% \\
12.5 \%\end{array}$ \\
\hline $\begin{array}{l}\text { Nail: short/ clean } \\
\text { Long/ dirty }\end{array}$ & $\begin{array}{c}5 \\
35\end{array}$ & $\begin{array}{l}12.5 \% \\
87.5 \%\end{array}$ \\
\hline
\end{tabular}

Table 2, depicted that majority of the children's personal hygiene were poor.
Table 3: Health Status of the Children (within 6 week)

\begin{tabular}{|c|c|}
\hline Diseases & Number \\
\hline Ring worm & 3 \\
Boils/ wound & 20 \\
Cuts & 5 \\
Eczema/redness & 6 \\
\hline Ear discharge & 10 \\
\hline Mumps/Enlarged & 2 \\
lymph node & \\
\hline Pneumonia & 10 \\
\hline Diarrhea/ vomiting & 20 \\
\hline Abdominal & 5 \\
enlargement & \\
\hline Nutritional status: & 12 \\
Garde I & 3 \\
Garde II & 2 \\
Garde III & 1 \\
Garde IV & \\
\hline
\end{tabular}

Table 3, depicted that among 40 children, major number of the children (20) were suffered from skin disease Boils and wound (20) gastrointestinal problems diarrhea/vomiting followed by pneumonia (10) and 18 children's were suffered from different grade of malnourished compaired with Indian Academic Classification(IAP).

Table 4: Behavioural status $(n=40)$

\begin{tabular}{|c|c|}
\hline Behavioural status: & \\
Nail Bitting & 6 \\
Diging nose & 4 \\
Thumb sucking & 10 \\
Bed wetting & 20 \\
\hline
\end{tabular}

Table 4, states that half of the children's behavior problem was bed wetting followed by thumb sucking (10) 


\section{Conclusion}

House hold surveys offer an excellent opportunity to screen a large size of underfive population with minimum resources. The present study was undertaken at Dharan-17( Naya Basti/sukumbasi Tole) where total 34 houses were selected and there were total 40 under 5 child(1-4years) resides. This study was conducted to find out status of personal hygiene, morbidity patterns, nutritional status, and behavioural patterns.

All of the parents were of low socioeconomic background with high percentage of illiteracy. This community was slum area (Sukumbashi Tole), where not facility of water supply and toilet facility at home was only three houses has toilet others use open field. All of the houses were Kachha.

The unhygienic personal hygiene among the children was prevalent to morbid pattern.

Most of the morbid conditions founded in the study were related to skin diseases $85 \%$ ( ring worm, boils/wound, cuts, eczema/ redness), ear infection $25 \%$, enlarged lymphnode $5 \%$, Pneumonia 25\%, Diarrhoea/ vomiting 50\%, abdominal enlargement $12.5 \%$ and malnutrition with different Grade $45 \%$.

Among the 40 children depicted behavioural problems as: nail bitting $15 \%$, digging nose
$10 \%$, Thumb sucking $25 \%$ and bed wetting $50 \%$.

Majority of the parent were not having health education regarding child care. The treat their child with home remedies, by faith healer then after third time they seek sick child with health personnel.

\section{References}

1. WHO constitute of the World Health Organization. Bulletin of the WHO2001;80(12):983-984.

2. UNICEF. The right to be child UNICEF India, Background paper 1994; 1-29.

3. Park K., Park's Textbook of Preventive and Social Medicine. 20 $^{\text {th }}$ ed. Prem Nagar, Jabalpur, India: M/s Banarsidas Bhanot; 2009. p. $471-77$.

4. Ghai OP, Paul VK, Bagga A. Essential Pediatric. $7^{\text {th }}$ Ed. New Delhi: CBS publisher; 2009.

5. Nepal Demography and health survey; 2006.

6. Adhikari RK, Krantz MR. Child Hood Nutrition. $3^{\text {rd }}$ ed. Kathmandu,Nepal. HLMC; 2001.

7. Haag J. School Health program; Calcutta oxford and IBHpublishing Company, 1994; 129.

Address of Correspondence: Dewa Adhikari, Nurding Director, Nobel Medical College, Biratnagar 


\section{Annuxere I}

\section{Health examination Tool}

Name of village :

Parents details
a. Father's 1. Name
2. Education
3. Occupation
b. Mother's 1. Name
2. Education
3. Occupation
4. Types of house
5. Water source
6. Types of Toilet

7. Name of child:
8. Age:
9. Gender: $\quad \mathrm{M} / \mathrm{F}$
10. Ethnic group:

11. Personal hygiene:
1. Skin
clean/ dirty
2. Hair
pediculosis/ dandruff/clean with combed/ dirty not combed
3. nails cut\& clean/uncut \& unclean
4. Nose clean/ Running nose
5. Clothes clean/ not clean
6. Bath a. daily,
b. twice a week
c. once a week d. others (specify)

\section{General appearance}
I. Built
a. normal
b. kyphosis
c. lordosis
d. rickets
e. scoliosis
f. others

\section{Anthropometric measurements}
a. height
$\mathrm{cm}$
b. weight
$\mathrm{kg}$

13. Skin
I. color
a. normal (healthy)/non- health
b. yellow/pallor

I4. Lesions at the time of study
a. Eczema
b. Ringworm
c. Scars
d. Impetigo
e. pediculosis
f. others (specify)

15. Eyes

I. Redness/ discharge

right/ left

II. Any lesion on lids

yes/no

III. Any lid abnormality

yes/no

IV. Sclera/ conjunctive

yes/ no

V. Bitot's spot

pallor/ jaundice/ healthy

VI. Corneal opacity

yes/ no

yes/ no

16. Ear

right / left

I. General condition

healthy/ unhealthy

II. Discharge

yes/ no

III. Pain

yes/ no 
17. Nasopharynx

I. sore throat/ Tonsillitis

yes/ no

II. Nasal obstruction

yes/ no

18. Mouth

I. Lips

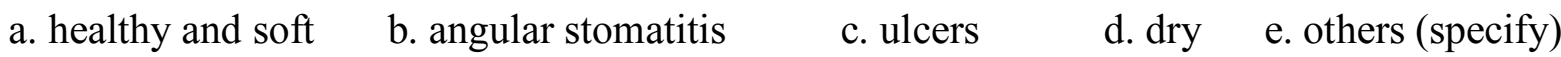

II. Tongue

a. healthy and soft

b. coated white

c. ulcers

d. dry

e. others (specify)

II. Teeth/gum
a. healthy
b. carries
c. swollen/ bleed
e. others (specify)

19. Thyroid enlarged/ not enlarged

20. Lymph nodes

(cervical/ inguinal/axillary palpable/ not palpable

Mobile/ not mobile painful/ not painful

Hard/ soft

21. Pulse rate

/ mit

regular/ irregular

22. Respiratory rate

/ mit

23. Lungs

24. Heart

25. Abdomen
a. general appearance
Normal/ abnormal
b. scars
yes/ no
c. Hernia
yes/ no
d. pain
yes/ no
e. liver/ spleen (enlarged)
yes/ no
f. others(specify)

26. Behavior status
I. Nail bitting
yes/ no
II. Thumb sucking
yes/ no

V. others (specify)

27. Locomotors system
a. upper limbs
normal/ deformed
b. lower limbs
normal/ deformed
c. reflexes
normal/ deformed

if any abnormal specify

28. Any communicable diseases within 6 months 